\title{
Communication
}

\section{Protein-Engineered Polymers Functionalized with Antimicrobial Peptides for the Development of Active Surfaces}

\author{
Ana Margarida Pereira ${ }^{1,2} \mathbb{D}$, Diana Gomes ${ }^{1,2} \mathbb{D}$, André da Costa ${ }^{1,2} \mathbb{D}$, Simoni Campos Dias ${ }^{3,4}$, Margarida Casal ${ }^{1,2}$ \\ and Raul Machado $1,2, *$ iD
}

1 CBMA (Centre of Molecular and Environmental Biology), Department of Biology, Campus de Gualtar, University of Minho, 4710-057 Braga, Portugal; ana.pereira@bio.uminho.pt (A.M.P.); dianacsgomes@gmail.com (D.G.); andrecosta@bio.uminho.pt (A.d.C.); mcasal@bio.uminho.pt (M.C.)

2 IB-S (Institute of Science and Innovation for Bio-Sustainability), Campus de Gualtar, University of Minho, 4710-057 Braga, Portugal

3 Genomic Sciences and Biotechnology Program, UCB-Brasilia, SgAN 916, Modulo B, Bloco C, Brasília 70790-160, Brazil; si.camposdias@gmail.com

4 Animal Biology Department, Campus Darcy Ribeiro, Universidade de Brasília, UnB, Brasília 70910-900, Brazil

* Correspondence: raulmachado@bio.uminho.pt

Featured Application: Recombinant protein polymers, genetically engineered to incorporate antimicrobial peptides, demonstrate a therapeutic effect. These materials can be employed for the development of antimicrobial and biocompatible surfaces/coatings produced by sustainable means.

check for updates

Citation: Pereira, A.M.; Gomes, D.; da Costa, A.; Dias, S.C.; Casal, M.; Machado, R. Protein-Engineered Polymers Functionalized with Antimicrobial Peptides for the Development of Active Surfaces. Appl. Sci. 2021, 11, 5352. https:// doi.org/10.3390/app11125352

Academic Editor:

Domenico Lombardo

Received: 26 April 2021

Accepted: 30 May 2021

Published: 9 June 2021

Publisher's Note: MDPI stays neutral with regard to jurisdictional claims in published maps and institutional affiliations.

Copyright: (c) 2021 by the authors. Licensee MDPI, Basel, Switzerland. This article is an open access article distributed under the terms and conditions of the Creative Commons Attribution (CC BY) license (https:/ / creativecommons.org/licenses/by/ $4.0 /)$.

\begin{abstract}
Antibacterial resistance is a major worldwide threat due to the increasing number of infections caused by antibiotic-resistant bacteria with medical devices being a major source of these infections. This suggests the need for new antimicrobial biomaterial designs able to withstand the increasing pressure of antimicrobial resistance. Recombinant protein polymers (rPPs) are an emerging class of nature-inspired biopolymers with unique chemical, physical and biological properties. These polymers can be functionalized with antimicrobial molecules utilizing recombinant DNA technology and then produced in microbial cell factories. In this work, we report the functionalization of rPBPs based on elastin and silk-elastin with different antimicrobial peptides (AMPs). These polymers were produced in Escherichia coli, successfully purified by employing non-chromatographic processes, and used for the production of free-standing films. The antimicrobial activity of the materials was evaluated against Gram-positive and Gram-negative bacteria, and results showed that the polymers demonstrated antimicrobial activity, pointing out the potential of these biopolymers for the development of new advanced antimicrobial materials.
\end{abstract}

Keywords: antimicrobial resistance; antimicrobial surfaces; antimicrobial films; recombinant protein polymers; silk-elastin proteins; elastin-like recombinamers; antimicrobial peptides

\section{Introduction}

The development of antimicrobial materials is a rapidly growing field, particularly for biomedical applications, demanding new versatile materials. The increasing number of infections caused by resistant bacteria and the low pace of discovery of new and efficient antibiotics necessitates new therapeutic approaches. Moreover, there is an increasing interest in the development of local antimicrobial treatment systems due to improved effectiveness and selectivity.

Natural structural proteins offer a wide range of properties with exceptional physical properties that meet those of synthetic polymers, with additional benefits of enhanced biocompatibility, low immunogenicity and higher degradability $[1,2]$. The unique physical properties of structural proteins are inherently linked to their composition, relying on the 
specific folding of building blocks that hierarchically assemble into well-defined structures. These building blocks have been used as design modules for the formulation of recombinant protein polymers (rPPs) with unique properties $[1,3]$. Recombinant DNA technology allows the biological synthesis of precisely defined rPPs with absolute control over size and composition. This technology is very powerful, enabling the design of multifunctional protein-based materials by fusing genes encoding for individual protein blocks, and even functional modules, into a single large gene [4]. For instance, the structure of rPPs can be genetically manipulated to incorporate the minimal consensus repeats of silk and elastin into the same molecule $[5,6]$ and to include bioactive domains such as antimicrobial peptides (AMPs) [7-9]. The versatility of this approach allows custom design of the structure of rPPs to obtain functional protein materials that can be processed into different active materials such as coatings, films and fiber mats [7-13].

Due to the unique balance of mechanical properties, biocompatibility and thermostability, elastin-like polypeptides/recombinamers (ELPs/ELRs) and silk-elastin-like proteins/recombinamers (SELPs/SELRs) have been widely studied for the development of biotechnological applications $[1,14,15]$. ELRs are composed of repeating amino acid building blocks with a typical sequence of VPGXG (V-valine, $\mathrm{P}$ - proline, $\mathrm{G}$-glycine, $\mathrm{X}$ is any amino acid except for proline) [16], characterized by a reversible temperature-dependent phase-transitional behavior $[17,18]$. SELPs are a group of copolymers consisting of alternate amino acid repetitions of silk blocks with sequence GAGAGS (A-alanine and S-serine) and elastin blocks, repeated in tandem [6]. These copolymers combine hard (silk) and soft (elastin) domains and can spontaneously form hydrogen-bonded antiparallel $\beta$-sheets, with the silk blocks imparting thermal and chemical stability and the elastin blocks reducing the overall crystallinity of the system, increasing its flexibility and water solubility $[5,19]$.

Antimicrobial peptides (AMPs) are promising alternatives to classical antibiotics due to their broad antimicrobial activity and remarkable efficacy [20]. Expressed in almost all living organisms and being part of the innate immune system, AMPs are usually amphipathic short peptides (fewer than 100 amino acid residues), with a positive net charge $(+2$ to +9$)$ at physiological $\mathrm{pH}[21,22]$. These natural molecules are particularly interesting as therapeutic agents due to their high selectivity toward bacterial cells over mammalian cells [23,24], and low probability to elicit bacterial resistance [25]. Although the underlying mechanisms of action of AMPs are still under active study, it is widely accepted that the basic principle involves the electrostatic interaction of the cationic AMPs with negatively charged components of the bacterial cell membranes [20,26,27]. This electrostatic interaction leads to binding and accumulation of AMPs on the surface of the membranes, promoting membrane depolarization and permeabilization [28]. Several models have been proposed to explain the antimicrobial effect of AMPs and their interaction with the bacterial cell membrane. The most widely described models include the "barrel stave" model, the "toroidal-pore" model and the "carpet" model—several reviews are available on this subject [20-22,28-30].

Due to their broad antimicrobial activity, AMPs have been immobilized onto the surface of materials to confer contact-killing antimicrobial activity [31-34]. Compared with soluble AMPs, the antimicrobial performance of surface-immobilized AMPs is generally reduced due to limited conformational freedom $[35,36]$. This can be compensated by increasing the density of immobilized AMPs or through introduction of flexible spacers [32,35]. Nevertheless, evidence with AMP-functionalized surfaces (e.g., films and coatings) indicates that the use of AMPs tethered into surfaces [37-41] or using genetically engineered fusion proteins for processing into films or coatings $[8,10,12,42]$ results in surfaces with contact-killing antimicrobial activity by disrupting the integrity of bacteria membranes, resulting in the leakage of intracellular content. The cationic nature of the AMPs probably displaces the divalent cations that maintain the structural integrity of the negatively charged surface of the bacteria, disrupting its integrity; thus, this effect by itself might be sufficient to generate a lethal outcome $[43,44]$. 
Our research group is pioneering the formulation of antimicrobial ELR-based materials by genetically engineering an ELR, comprising 200 repetitions of the VPAVG sequence (A200), to include the DNA sequence of AMPs $[8,12,45]$. We have produced antimicrobial ELR-based films through functionalization with the antimicrobial peptides ABP-CM4 [12], a 35 amino acid peptide from the hemolymph of silkworm, and BMAP18 [8], an 18-amino acid truncated variant of bovine myeloid antimicrobial peptide-28. A200 is characterized by an acute thermal hysteresis behavior and the ability to self-assemble into spherical nanoparticles at temperatures above $33^{\circ} \mathrm{C}[46,47]$; we explored this unique behavior for the purification of recombinant hepcidin [45], a 25 amino acid human liver antimicrobial peptide, and suggested its potential application as antimicrobial drug delivery platform.

The aim of this study was to investigate the potential of using both ELRs and SELPs functionalized with AMPs for the development of new antimicrobial surfaces (e.g., films / coatings). Moreover, we also provide a comparison on the antimicrobial performance of SELP- and ELR-based materials obtained while using water and formic acid as solvents for processing. To achieve this, functional SELP hybrids were obtained by using SELP-59A [6] as a structural module and the antimicrobial peptides ABP-CM4, BMAP18, hepcidin and Synoeca-MP, an antimicrobial peptide isolated from Synoeca surinama social wasp [48], as antimicrobial functional modules. These AMPs were chosen due to their broad and potent antimicrobial activity against different microorganisms [48-54]. While the mechanism of action for Synoeca-MP remains to be elucidated, it has been proposed that ABP-CM4, BMAP18 and hepcidin promote cell membrane depolarization, permeabilization and disruption $[51,52,54,55]$. SELP-59-A is a protein copolymer designed and synthesized by our research group [6] consisting of nine tandem repetitions of S5E9, where S is the silk block with sequence GAGAGS and $E$ is the elastin block with sequence VPAVG. This recombinant protein polymer demonstrated good mechanical properties and cytocompatibility, as well as a high versatility of processing $[5,56]$. To expand the range of antimicrobial ELR-based materials, we also describe the production of hybrid ELRs comprising A200 as a structural module and hepcidin and Synoeca-MP as functional modules. Hexafluoroisopropanol [57] and formic acid $[8,12,13]$ are commonly used as solvents for rPP processing such as those described here. Here, we explored the use of water as a "greener" and mild alternative for solvent casting. All the recombinant protein materials were used for the production of free-standing films by solvent casting using water and formic acid as solvents and evaluated for their antimicrobial performance against Gram-negative and Gram-positive bacteria following adapted ISO guidelines.

\section{Materials and Methods}

\subsection{Preparation of Genetic Constructions}

Genetic constructions were obtained by standard genetic engineering techniques using DNA sequences optimized for Escherichia coli codon usage, following previously described methodologies [45]. Briefly, for A200-based constructions, the genetic sequences coding for AMPs were chemically synthesized with flanking NdeI and KpnI restriction sites (Genscript) and cloned at the N-terminus of A200, previously cloned into a modified pET25b(+) (Novagen) expression plasmid [46]. For the AMP-SELP constructions, the genetic sequences for AMPs were chemically synthesized with flanking NdeI restriction sites (Genscript) and cloned at the N-terminus of SELP-59-A, previously cloned into a modified pET25b(+) (Novagen) expression plasmid, containing a poly-histidine tag (6x His) [6]. All the genetic constructions (Tables S1 and S2), Synoeca-A200 (Syn-A200), Synoeca-SELP (Syn-SELP), hepcidin-A200 (Hep-A200), hepcidin-SELP (Hep-SELP), ABPCM4-SELP (CM4-SELP) and BMAP18-SELP were confirmed by DNA sequencing (Eurofins). The final expression plasmids were transformed into E. coli BL21(DE3) for recombinant protein production. 


\subsection{Protein Production and Purification}

All proteins-Hep-A200, MW = 87.9 kDa; Syn-A200, MW = 86.8 kDa; Hep-SELP, $\mathrm{MW}=60.0 \mathrm{kDa}$; Syn-SELP, MW = 58.6 kDa; CM4-SELP, MW = 60.8 kDa; BMAP18-SELP, $\mathrm{MW}=59.2 \mathrm{kDa}$ )—were expressed in E. coli BL21(DE3) by means of auto-induction [6]. Cell cultures were allowed to grow for $22 \mathrm{~h}$ at $37^{\circ} \mathrm{C}$ and $200 \mathrm{rpm}$, with a volumetric ratio of 1:4 in Terrific Broth (12 g tryptone, $24 \mathrm{~g}$ yeast extract, $5.04 \mathrm{~g}$ glycerol, $12.54 \mathrm{~g} \mathrm{~K}_{2} \mathrm{HPO}_{4}$, $2.31 \mathrm{~g} \mathrm{KH}_{2} \mathrm{PO}_{4}$, per liter), supplemented with $2 \mathrm{~g} / \mathrm{L}$ lactose for auto-induction (TBlac), and $100 \mathrm{mg} / \mathrm{L}$ ampicillin (AMP-SELP) or $50 \mathrm{mg} / \mathrm{L}$ kanamycin (AMP-A200).

After protein production, bacterial cells were collected by centrifugation, resuspended in TE buffer solution (50 mM Tris- $\mathrm{HCl}+1 \mathrm{mM}$ EDTA at $\mathrm{pH}$ 8.0) and disrupted by sonication using a Vibra cell ${ }^{\mathrm{TM}} 75043$ ultrasonic liquid processor (Bioblock Scientific) with a $25 \mathrm{~mm}$ diameter probe ( $3 \mathrm{~s}$ pulse on, $9 \mathrm{~s}$ pulse off, total sonication time: $10 \mathrm{~min}$ ). The $\mathrm{pH}$ of the crude cell lysate was adjusted to 3.5 with $1.6 \mathrm{M} \mathrm{HCl}$ to precipitate endogenous $E$. coli contaminants $[6,45]$ and removed by centrifugation at $11,500 \times g$ for $20 \mathrm{~min}$ at $4{ }^{\circ} \mathrm{C}$. Samples were kept at ice-cold temperature during the entire process. Purification of AMPA200 proteins (Hep-A200 and Syn-A200) was achieved by means of inverse transition cycling (ITC) based on previously described methodologies $[45,46]$. Briefly, the AMPA200 proteins were subjected to three cycles of hot $\left(37^{\circ} \mathrm{C}\right)$ and cold $\left(4{ }^{\circ} \mathrm{C}\right)$ incubation ( $2 \mathrm{~h}$ at each temperature) and centrifugation steps $(11,500 \times g$ for $20 \mathrm{~min}$ ) in ultrapure water (mQ; Milli-Q ${ }^{\circledR}$, Millipore). AMP-SELP proteins were purified by ammonium sulfate precipitation with $20 \%$ saturation followed by dialysis against $\mathrm{mQ}$ water (refer to [6] for detailed description), using natural cellulose with a 12,000-14,000 Da molecular weight cut-off (Medicell Membranes Ltd.). Protein production and purification was assessed by sodium dodecyl sulfate-polyacrylamide gel electrophoresis (SDS-PAGE) on a 10\% acrylamide gel with $0.3 \mathrm{M}$ copper chloride $\left(\mathrm{CuCl}_{2}\right)$ staining. Purified polymer fractions were freeze-dried (Christ Alpha 2-4 LD Plus from Bioblock Scientific) and stored at room temperature prior to use.

\subsection{Western Blot Analysis of AMP-SELP}

Following 10\% SDS-PAGE electrophoresis separation of pure solutions of AMP-SELP, protein bands were transferred onto a nitrocellulose membrane at $100 \mathrm{~V}$ for $1 \mathrm{~h}$. The membrane was then blocked for $1 \mathrm{~h}$ with $5 \%$ non-fat dried milk in TBS-T buffer (50 mM Tris$\mathrm{HCl}, 150 \mathrm{mM} \mathrm{NaCl}, 0.05 \%$ Tween 20 at pH 8), washed with TBS-T and incubated overnight with mouse monoclonal anti-polyHistidine antibody (Sigma-Aldrich) diluted 1:3000 in the blocking solution. Following incubation with the primary antibody, membrane was washed with TBS-T and incubated with goat anti-mouse IgG peroxidase (HRP) antibody (Sigma-Aldrich) diluted 1:5000 in the blocking solution. Protein detection was assessed by chemiluminescence using the ECL detection system (Merck Millipore) and a Chemi-Doc XRS system (BioRad).

\subsection{Preparation of Free-Standing Films}

Films of AMP-A200 and AMP-SELP were prepared by solvent casting using doubledistilled water $\left(\mathrm{ddH}_{2} \mathrm{O}\right)$ or formic acid (98\%-100\%, Merck) as solvents. Pure lyophilized protein was dissolved in the corresponding solvent at ice-cold temperature to concentrations of $10 \%(w / v)$ for AMP-A200 and 3\% (w/v) for AMP-SELP, and mixed until complete dissolution was achieved. A volume of $100 \mu \mathrm{L}$ of each protein solution was cast onto polytetrafluoroethylene (PTFE, Teflon ${ }^{\circledR}$ ) molds with $10 \mathrm{~mm}$ diameter and allowed to dry at room temperature under extraction. After complete solvent evaporation, films were gently peeled off from the molds. The AMP-SELP free-standing films were subjected to a post-processing treatment with methanol-saturated air at room temperature for $48 \mathrm{~h}$ in a desiccator to promote water insolubility [5] and air-dried at room temperature for at least $48 \mathrm{~h}$ before characterization. 


\subsection{Structural Characterization of AMP-SELP Films}

Structural changes induced by the methanol treatment in the AMP-SELP films were assessed by attenuated total reflection Fourier-transform infrared (ATR-FTIR) spectroscopy using a Perkin Elmer Spectrum Two ${ }^{\mathrm{TM}}$ spectrometer with a DTGS (deuterated triglycine sulfate) detector, coupled with a single reflection diamond UATR (universal attenuated total reflectance, Perkin Elmer). Spectra were collected in the range between 4000 and $600 \mathrm{~cm}^{-1}$, after 64 scans with a resolution of $4 \mathrm{~cm}^{-1}$ and automatic correction of atmospheric $\mathrm{CO}_{2} / \mathrm{H}_{2} \mathrm{O}$. Spectra analysis was conducted in the amide I band region $\left(1600-1700 \mathrm{~cm}^{-1}\right)$ by second derivatization and Gaussian curve fitting using OriginPro 9.0 software (OriginLab, Northampton, MA) [58]. For a reliable comparison between the secondary structure assignment of the different samples, curve fitting was performed with the same set of parameters. The contribution of each fitted component to the amide I band was estimated by integration of the area under the curve and normalizing for the total area of amide I.

\subsection{Evaluation of Antimicrobial Activity}

The antimicrobial activity of the polymeric films was assessed by direct contact against E. coli HB101 and S. aureus ATCC6538 using an adapted version of ISO 22196 [12]. Films were sterilized by UV exposure for $30 \mathrm{~min}$ and transferred to sterile non-treated polystyrene (PS) flat bottom 24 well plates. The surface of the films was inoculated with $50 \mu \mathrm{L}$ of bacterial cell suspension $\left(1 \times 10^{6} \mathrm{CFUs} / \mathrm{mL}\right)$ and incubated for $120 \mathrm{~min}$ at $37^{\circ} \mathrm{C}$. After incubation, $950 \mu \mathrm{L}$ of sterile $0.87 \% \mathrm{NaCl}$ solution was added and carefully agitated by gently pipetting up and down 10 times, followed by plating $100 \mu \mathrm{L}$ of serial diluted cell suspensions on LB agar (10 g tryptone, $5 \mathrm{~g}$ yeast extract, $10 \mathrm{~g} \mathrm{NaCl}, 15 \mathrm{~g}$ agar, per liter). Cell suspensions inoculated in empty wells (without protein films) were used as negative control for antibacterial activity. Antimicrobial assays were performed in triplicate at different days with three replicates each. Results were expressed as lethality percentage $(\%$ kill) calculated by the equation:

$$
\% \text { kill }=\frac{\text { CFUs }(\text { control })-C F U s(\text { sample })}{\text { CFUs }(\text { control })} \times 100
$$

\subsection{Statistical Analysis}

Two-way analysis of variance (ANOVA) with Bonferroni's post-test and 95\% confidence level was carried out with GraphPad Prism 6 software. Results were presented as mean values \pm standard deviation (SD), and $p \leq 0.05$ was considered statistically significant. All experiments were performed in triplicate and repeated at least three times in independent days.

\section{Results and Discussion}

\subsection{Production and Purification of Recombinant AMP-A200 and AMP-SELP}

All recombinant proteins (Hep-A200, Syn-A200, Hep-SELP, Syn-SELP, CM4-SELP and BMAP18-SELP) were successfully produced in E. coli BL21(DE3) at high expression levels (see Figures $1 \mathrm{~b}$ and $2 \mathrm{a}$ for representative samples). 


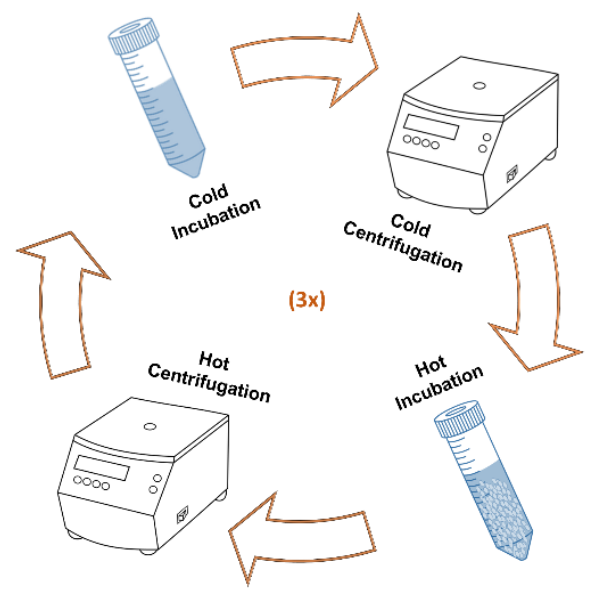

(a)

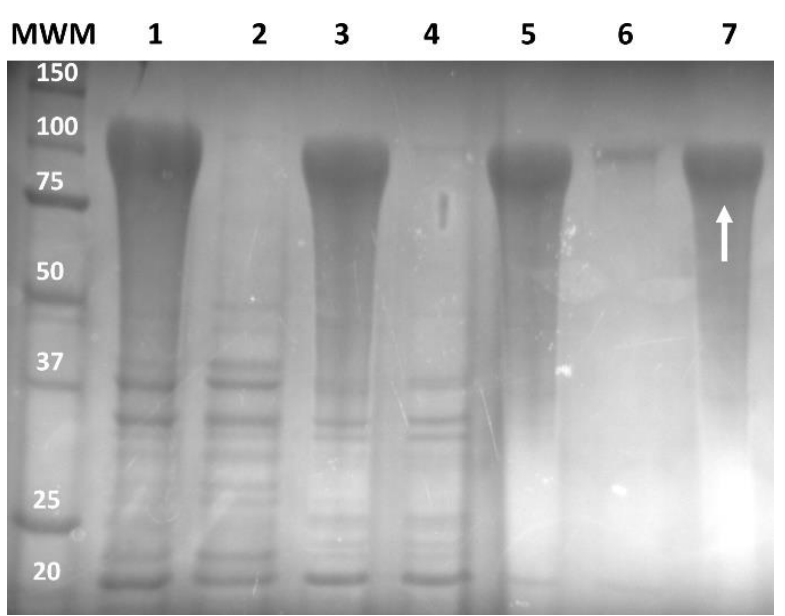

(b)

Figure 1. Purification of AMP-A200-based protein polymers. (a) Schematic representation of the purification process by ITC. (b) Representative SDS-PAGE analysis of purification for Syn-A200. After sonication and acidification to pH 3.5, the insoluble debris was removed by centrifugation and the recombinant protein polymer was purified from the clear supernatant (lane 1) by ITC using hot/cold cycles. For each cycle, the protein-enriched solution was heated to $37{ }^{\circ} \mathrm{C}$ and then centrifuged at the same temperature. The resulting hot supernatant was discarded (lanes 2, 4 and 6) and the precipitated protein was resuspended in ice-cold $\mathrm{ddH}_{2} \mathrm{O}$. After complete resuspension, the solution was centrifuged at $4{ }^{\circ} \mathrm{C}$, and the resulting cold supernatant (lanes 3, 5 and 7) was submitted to a new cycle. A pure protein polymer fraction (indicated by the white arrow) was obtained after three complete cycles. MWM-molecular weight marker (Precision Plus Protein Unstained Standards from Bio-Rad) in kDa; 1 -cycle one, cold supernatant; 2-cycle one, hot supernatant; 3 -cycle two, cold supernatant; 4-cycle two, hot supernatant; 5—cycle three, cold supernatant; 6-cycle three, hot supernatant. Gel was stained with $0.3 \mathrm{M} \mathrm{CuCl}_{2}$.

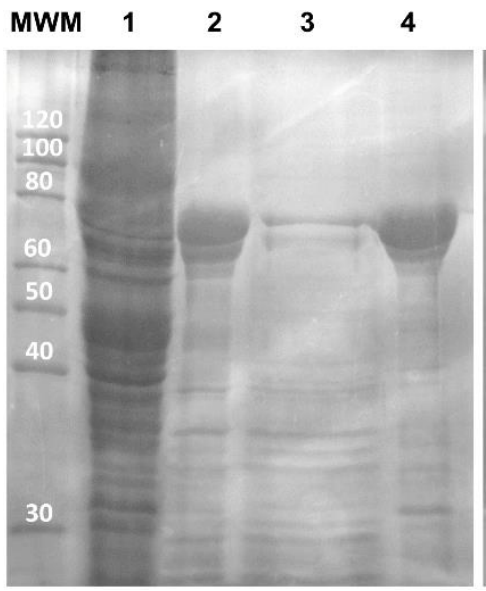

(a)

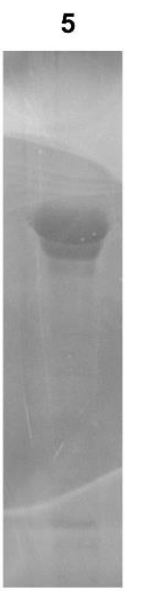

Figure 2. (a) Representative SDS-PAGE analysis of the purification process for BMAP18-SELP by salting out with ammonium sulfate at 20\% saturation: MWM-molecular weight marker (GRS Unstained Protein Marker from Grisp) in kDa; 1—crude cell lysate after sonication; 2-supernatant after acidification at $\mathrm{pH} 3.5 ; 3$ - supernatant after salting out; 4-fraction of the precipitated sample after salting out; 5-dialyzed protein sample. Gel was stained with $0.3 \mathrm{M} \mathrm{CuCl}_{2}$. (b) Representative SDS-PAGE (image on the left) and Western blot (image on the right) analysis of pure BMAP18-SELP (6) with unstained SDS-PAGE standard molecular weight marker (MWM, in kDa; BioRad).

Purification of the A200-based protein polymers was achieved by ITC, resulting in highly pure protein factions (Figure 1). After three heating/cooling cycles (Figure 1a), a pure protein fraction was obtained, as demonstrated by presence of a single band around $100 \mathrm{kDa}$ (lane 7, Figure 1b). 
Purification of AMP-SELP was achieved by a non-chromatographic method involving the use of ammonium sulfate at $20 \%$ saturation for the selective precipitation of SELP [6]. Analysis of the electrophoretic pattern of purified BMAP18-SELP (used in Figure 2 as representative sample) revealed the presence of two strong bands at approximately 60 and $80 \mathrm{kDa}$ and some less intense bands at lower molecular weights (Figure 2a). Western blot analysis using antibodies to the His tag revealed a similar band profile (Figure 2b), characterized by a strong band corresponding to BMAP18-SELP and unknown lower molecular weight protein bands. Overall, ammonium sulfate precipitation demonstrably resulted in pure AMP-SELP fractions.

The same electrophoretic pattern and Western blot results were observed for the remaining SELP-based constructions (Figure S1). The abnormal gel mobility to higher molecular weights than expected is a consequence of the hydrophobic nature of the proteins and has been previously observed for other recombinant protein polymers $[6,45,46,59,60]$. After purification and lyophilization, the lyophilized product was weighed, resulting in volumetric productivities per liter of production of $50 \mathrm{mg} / \mathrm{L}$ for Hep-A200, $90 \mathrm{mg} / \mathrm{L}$ for Syn-A200, $90 \mathrm{mg} / \mathrm{L}$ for Hep-SELP, $73 \mathrm{mg} / \mathrm{L}$ for Syn-SELP, $120 \mathrm{mg} / \mathrm{L}$ for CM4-SELP and $70 \mathrm{mg} / \mathrm{L}$ for BMAP18-SELP.

\subsection{Secondary Structure Analysis of AMP-SELP Films}

Maintenance of structural integrity is fundamental in the development of materials, especially for applications that require contact with aqueous environments such as culture media or body fluids. Due to the intrinsic thermal hysteresis behavior of A200, both Hep-A200 and Syn-A200 films were stable over a wide range of temperatures without the need of crosslinking agents to promote structure stabilization [12,13]. However, ascast SELP materials based on the SELP-59-A backbone are highly water soluble, limiting their potential application. Nonetheless, this limitation can be surpassed by treatment with methanol, leading to water insolubility by inducing a physical crosslinking through the formation of hydrogen-bonded $\beta$-sheets $[5,56]$. In this study, the AMP-SELP films were exposed to a methanol-saturated atmosphere for $48 \mathrm{~h}$, and structural changes were evaluated by ATR-FTIR spectroscopy. Secondary structure analysis was performed based on the amide I region (1600 to $1700 \mathrm{~cm}^{-1}$ ), a sensitive spectral region used for protein studies, which occurs mostly from $\mathrm{C}=\mathrm{O}$ stretching vibrations [61-63]. For all samples, the infrared spectrum of the non-treated films was characterized by a broad amide I absorption band centered at approximately $1628 \mathrm{~cm}^{-1}$ with a pronounced shoulder around $1646 \mathrm{~cm}^{-1}$ (Figure S2), indicating the presence of $\beta$-sheets and a relevant contribution from random coils, respectively [5]. After the methanol treatment, the amide I band was narrower and shifted to approximately $1623 \mathrm{~cm}^{-1}$, indicating that major contributions arise from $\beta$-structures and less from other secondary structures $[5,58]$. Since the broad amide I band collected from spectra collected results from the overlapping components arising from the various secondary structure elements [64], band-narrowing techniques such as second derivative analysis are pivotal for a more detailed characterization of protein conformation, thus providing the basis for the quantitative estimation of protein secondary structure [65-67]. Quantitative secondary structure analysis of AMP-SELPs was performed by second derivative analysis and curve fitting methods, with assignment of structural conformations by reference to literature $[58,63]$ (Table S3).

After the methanol treatment, the $\beta$-sheet content of all films demonstrated an overall increase of more than $8 \%$ for films prepared with water and more than $3 \%$ for films prepared with formic acid in relation to the untreated samples (Table 1). These results indicate that methanol induced a molecular reorganization (Figure S2), leading to the formation of additional hydrogen-bonded $\beta$-sheets that resulted in water insolubility. 
Table 1. Beta-structure content of AMP-SELP films, produced from water and formic acid solutions, after and before methanol (MetOH) treatment. Results presented as fractional distribution of total $\beta$-structure content determined by second derivative and Gaussian curve fitting.

\begin{tabular}{ccccc}
\hline \multirow{2}{*}{ Sample } & \multicolumn{2}{c}{ Water } & \multicolumn{2}{c}{ Formic Acid } \\
\cline { 2 - 5 } & Untreated & MetOH-Treated & Untreated & MetOH-Treated \\
\hline Hep-SELP & $45.62 \%$ & $54.91 \%$ & $44.90 \%$ & $48.48 \%$ \\
Syn-SELP & $38.40 \%$ & $54.56 \%$ & $48.70 \%$ & $51.86 \%$ \\
CM4-SELP & $40.86 \%$ & $49.75 \%$ & $44.42 \%$ & $55.68 \%$ \\
BMAP18-SELP & $37.62 \%$ & $55.02 \%$ & $45.95 \%$ & $52.7 \%$ \\
\hline
\end{tabular}

\subsection{Antimicrobial Activity of AMP-ELR and AMP-SELP Films}

The antimicrobial activity of Hep-A200, Syn-A200, Hep-SELP, Syn-SELP, CM4-SELP and BMAP18-SELP films (produced from aqueous or formic acid solutions) was evaluated against S. aureus ATCC6538 (Gram-positive) and E. coli HB101 (Gram-negative) by direct contact after $120 \mathrm{~min}$.

Analysis of antibacterial assays reveals that antimicrobial performance is highly dependent on the structural (ELR or SELP) and functional (AMP) modules and less dependent on the solvent used for film production, although films produced with formic acid display slightly higher average \% kill values. Overall, the AMP-A200 films demonstrated better antimicrobial performance than the AMP-SELP films, independently of the solvent used (Figure 3).

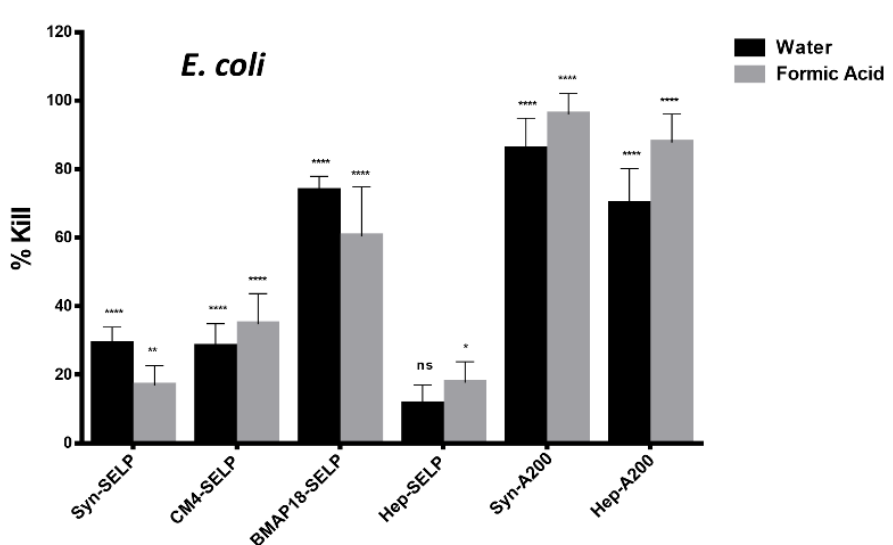

(a)

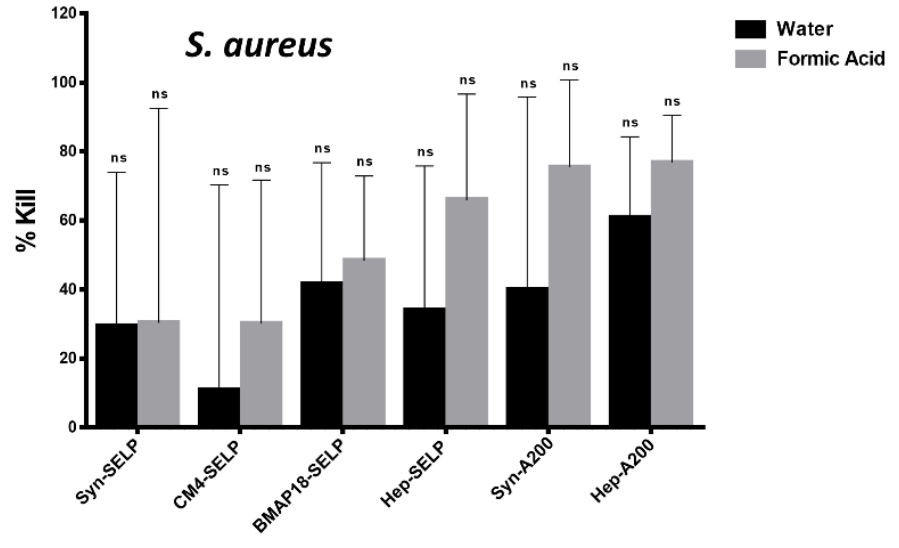

(b)

Figure 3. Antimicrobial activity of AMP-SELP and AMP-A200 hybrid materials assessed by direct contact with the surface of the films against (a) Escherichia coli and (b) Staphylococcus aureus. Cell suspensions inoculated in empty wells were used as reference for $100 \%$ survival. Error bars represent means \pm SD (ns, non-significant; ${ }^{*} p \leq 0.05 ;{ }^{* *} p \leq 0.01$; ${ }^{* * *} p \leq 0.001 ;{ }^{* * * *} p \leq 0.0001$ ). Experiments were performed in triplicate in independent days with three replicates each (see Tables S4 and S5 for CFU enumeration). No statistical significance was found between films prepared using water or formic acid as solvents.

Syn-SELP and Hep-SELP films produced using formic acid as solvent show average lethality percentage (\% kill) values for E. coli near 17\%, whereas Syn-A200 and Hep-A200 films produced using the same solvent demonstrated average values of approximately $96 \%$ and $88 \%$, respectively (Figure $3 \mathrm{a}$, Table 2 ). This same trend is observed for CM4SELP and BMAP18-SELP compared to reference values obtained in previous works $[8,12]$ (Table 2). The SELP-based films produced from formic acid present values of $\%$ kill around $35 \%$ and $60 \%$ for CM4-SELP and BMAP18-SELP, respectively, whereas this value increases to $86 \%$ and $100 \%$ using A200 as a structural backbone (Table 2). The distinct antimicrobial performance observed for AMP-A200 and AMP-SELP films is possibly due to the different conformations adopted by the structural modules (SELP and ELR) in the protein polymers. ELRs adopt a highly hydrated structure with conformational 
flexibility $[68,69]$. This flexibility favors the ability of the AMPs to interact with bacteria. In contrast, the methanol-treated SELPs adopt a more rigid crystalline structure, characterized by antiparallel hydrogen-bonded $\beta$-sheet structures (silk II-like) [5,70,71]. As the AMPs are fused to the N-terminal of the SELP, that is, to the silk blocks, the conformational flexibility of the AMPs is therefore restricted, limiting the ability of AMP moieties to contact with bacteria.

Table 2. Percentage lethality (\% kill) of the different protein polymer films after $2 \mathrm{~h}$ incubation at $37^{\circ} \mathrm{C}$ with Escherichia coli and Staphylococcus aureus. Films were produced by solvent casting using (a) water and (b) formic acid as solvents. Experiments were performed in triplicate in independent days with three replicates each.

\begin{tabular}{cccc}
\hline Sample & \% Kill (E. coli) $^{\text {(a) }}$ & \% Kill (S. aureus) & Reference \\
\hline Hep-A200 $^{\text {(b) }}$ & $69.9 \pm 10.2$ & $60.8 \pm 23.5$ & This work \\
Hep-A200 $^{\text {(b) }}$ & $87.7 \pm 8.3$ & $76.7 \pm 13.7$ & This work \\
Syn-A200 $^{\text {(a) }}$ & $85.9 \pm 9.0$ & $75.4 \pm 25.4$ & This work \\
Syn-A200 $^{\text {(b) }}$ & $95.9 \pm 6.2$ & $85.6 \pm 8.2$ & This work \\
CM4-A200 $^{\text {(b) }}$ & $86.5 \pm 0.7$ & $69.7 \pm 4.5$ & {$[12]$} \\
BMAP18-A200 $^{\text {(b) }}$ & 100.0 & $98.8 \pm 2.0$ & {$[8]$} \\
Hep-SELP $^{\text {(a) }}$ & $11.4 \pm 5.5$ & $33.9 \pm 41.9$ & This work \\
Hep-SELP $^{\text {(b) }}$ & $17.7 \pm 6.1$ & $65.9 \pm 30.8$ & This work \\
Syn-SELP $^{\text {(a) }}$ & $28.9 \pm 4.9$ & $29.3 \pm 44.7$ & This work \\
Syn-SELP $^{\text {(b) }}$ & $16.9 \pm 5.8$ & $30.3 \pm 62.2$ & This work \\
CM4-SELP $^{\text {(a) }}$ & $28.1 \pm 6.8$ & $10.7 \pm 59.6$ & This work \\
CM4-SELP $^{\text {(b) }}$ & $34.8 \pm 8.9$ & $30.1 \pm 4.8$ & This work \\
BMAP18-SELP $^{(a)}$ & $73.7 \pm 4.2$ & $41.5 \pm 35.3$ & This work \\
BMAP18-SELP $^{\text {(b) }}$ & $60.4 \pm 14.4$ & $48.4 \pm 24.5$ & This work \\
\hline
\end{tabular}

Comparing the mean values of lethality percentage (\% kill) against the tested bacteria, best results were generally obtained against E. coli than against S. aureus (Figure 3). The antibacterial assays against $S$. aureus demonstrated high standard deviation (SD) values, which are a consequence of the ability of S. aureus to grow as planktonic aggregates [72], thus reducing the direct contact with the films. This observation has been previously reported in a similar direct contact assay using CM4-A200 films [12] and fiber mats [13]. Indeed, scanning electron microscopy micrographs clearly demonstrated the ability of $S$. aureus to form aggregates reducing the contact of the overall microbial community with the film surface [12]. Similarly, in the present study, the antimicrobial action of the films was mediated by direct contact, in which cells must be available to contact with the film surface. If cells are able to form aggregates, only those in contact with the film surface are subjected to an antimicrobial effect, explaining the high variability of the assay. Still, analysis of the mean values demonstrates that, overall, the AMP-ELR films demonstrate a better antibacterial performance than AMP-SELP films.

In addition to the structural backbone (ERL or SELP), the antimicrobial activity was also influenced by the type of AMP. Comparing the effect of the functional module in the antibacterial activity of the AMP-SELP films against $E$. coli, best results were obtained with BMAP18 with average $\%$ kill values greater than $60 \%$, whereas the lowest antimicrobial performance was observed for Hep-SELP with \% kill values lower than 20\% (Table 2). The apparent low antimicrobial performance of Hep-SELP films may be due to the secondary structure of hepcidin. Unlike Synoeca, CM4 and BMAP18, which show a linear $\alpha$-helix secondary structure in membrane-mimicking environments $[48,73,74]$, hepcidin forms a less flexible $\beta$-hairpin structure, with a central core cross-linked by four disulfide bonds [75] that might intertwine with SELP $\beta$-sheets, compromising the peptide interaction with bacteria membranes.

Regarding the assays performed with E. coli (Figure 3a), results revealed that, for the confidence interval considered, all polymer films (except for Hep-SELP films prepared 
using water as solvent) are statistically significant, demonstrating the antimicrobial effect of these films.

The antimicrobial activity observed for the fusion proteins is attributed to the functional module (AMPs) and not to the structural module (A200 or SELP). Previously, we have demonstrated that CM4-A200 displays potent antimicrobial activity against $P$. aeruginosa, reaching lethality percentage values of ca. 97\% [12]. When compared with other A200-based fusion proteins (BMP2-A200: bonemorphogenetic protein-2 linked with A200 and prosubtilisin-A200: prosubtilisin enzyme linked with A200) the antimicrobial activity was found to be very low (ca. 20\% for BMP2-A200) or even absent (proliferation of ca. 14\% for prosubtilisin-A200) [12]. These results indicated that the antimicrobial performance was attributed to the AMP and not to the structural A200. In a similar way, the antimicrobial activity of non-functionalized SELPs (SELP without AMPs) demonstrated to be statistically non-significant compared with the control (Figure S3). Finally, the attribution of antimicrobial activity to the diffusion of eroded molecules is very unlikely as antimicrobial assays utilizing the Kirby-Bauer test demonstrated the absence of inhibition halos (unpublished data). We have previously demonstrated that CM4-A200 and BMAP18-A200 do not show inhibition halos in disk diffusion assays (Kirby-Bauer test) but exert a strong antimicrobial effect mediated by direct contact $[8,12]$.

\section{Conclusions}

In this study, we report the fabrication of new antimicrobial protein-based polymers with different structural backbones (structural module), namely SELP-59-A, a silk-elastinlike protein able to form self-structured $\beta$-sheet structures, and A200, an elastin-like recombinamer characterized by a more flexible conformation. The protein polymers were genetically engineered to include functional modules consisting of the amino acid sequences for antimicrobial peptides hepcidin, ABP-CM4 and BMAP18, as well as the recently isolated Synoeca-MP (Table S6). All constructs were successfully produced in E. coli, purified by simple non-chromatographic approaches and processed into free-standing films using water and formic acid as solvents. No statistically significant differences were observed in the antimicrobial activity of films produced with water or with formic acid, indicating the feasibility of using a water as mild and "green" alternative to more harsh chemicals. However, evaluation of the antimicrobial activity of the films indicates that the structural backbone plays a central role in antimicrobial performance suggesting that AMPs should be conformationally free to exert their antimicrobial effect. While the AMP-ELR films were highly effective in exerting an antimicrobial effect against E. coli and S. aureus, we propose that the more rigid structure of the AMP-SELP materials restricts the ability of the AMPs to interact with bacterial cells and consequently results in a more limited performance. A strategy to overcome this limitation could be through the inclusion of flexible glycine/serine spacers in the genetic design to improve the conformational freedom of the AMPs [76,77], thereby increasing their accessibility. Bagheri et al. [36] demonstrated that the presence of flexible spacers and their length are determinant factors for antimicrobial activity since the presence of the spacer can enable peptide insertion into the cell. On the other hand, the antimicrobial activity of AMPs can be lost when immobilized on surfaces without the presence of a spacer $[38,78]$. This supports our assumption that increased antibacterial activity can be achieved by introducing flexible spacers in the genetic design. Nevertheless, SELP-based antimicrobial biomaterials can be promising opportunity for novel materials, as SELPs combine the elasticity, resilience and solubility of elastin with the mechanical strength and versatility of processing of silk [5,79].

Analysis of antimicrobial results against $S$. aureus revealed a high variability because of its ability to form cell aggregates thus reducing the contact with the antimicrobial surface. This high variability could be reduced by lowering the number of cells in the inoculum, so as to ensure that the majority of bacteria are placed in contact with the film surface. As such, although the antimicrobial assays were performed based on ISO 22196, we suggest 
that results should be critically analyzed upon assessing the antimicrobial performance of surfaces while using cells with the ability to grow in aggregates.

Overall, the findings of the present study represent an important contribution towards the rational design of genetically engineered protein polymers functionalized with antimicrobial peptides and provide cues for a next generation of antimicrobial materials.

Supplementary Materials: The following are available online at https:/ /www.mdpi.com/article/ 10.3390/app11125352/s1, Figure S1: SDS-PAGE (a) and Western blot (b) analysis of pure BMAP18SELP (2), CM4-SELP (3) and Hep-SELP (4) using anti-polyHistidine antibodies and pure SELP (1) as control. MWM-molecular weight marker (broad range unstained SDS-PAGE Standard from Bio-Rad) in kDa.; Figure S2: Curve-fitted deconvoluted spectrum with band assignment for SELPbased films. The bands filled in green represent contributions of $\beta$-structures. The narrowing of the amide I band and the shift of the peak center to lower wavenumber after methanol treatment indicates a greater contribution arising from $\beta$-sheets.; Figure S3. Antimicrobial activity of nonfunctionalized SELP (SELP-59-A without AMPs) assessed by direct contact with the surface of the films against $E$. coli and S. aureus. Cell suspensions inoculated in empty wells were used as reference for $100 \%$ survival. No statistically significant differences were observed between SELP films and the control, indicating the absence of antimicrobial activity; Table S1: List of genetic constructions used in this work. Molecular weight was calculated with Expasy Compute $\mathrm{pI} / \mathrm{Mw}$ tool (https://web.expasy.org/compute_pi/; accessed on 30 October 2020); Table S2: Amino acid sequence and size of antimicrobial peptides. Molecular weight was calculated with Expasy Compute $\mathrm{pI} / \mathrm{Mw}$ tool (https: / / web.expasy.org/compute_pi/; accessed on 30 October 2020); Table S3: Vibrational band assignments used for conformational structure quantification (Hu et al., 2006; Machado et al., 2015; Pereira et al., 2017); Table S4: Number of CFUs obtained in the antimicrobial assays of AMP-SELP and AMP-A200 films against Escherichia coli. Experiments were performed in triplicate in independent days ( $n=1, n=2$ and $n=3$ ) with three replicas each. Each value corresponds to the number of CFUs obtained in a plate after a 1:20 dilution in sterile saline solution. Each set of three values correspond to replicates. Letters in superscript correspond to the respective control in each independent day (n). Values between brackets were excluded from statistical analysis due to high deviating values or due to contamination; Table S5: Number of CFUs obtained in the antimicrobial assays of AMP-SELP and AMP-A200 films against Staphylococcus aureus. Experiments were performed in triplicate in independent days ( $n=1, n=2$ and $n=3)$ with three replicas each. Each value corresponds to the number of CFUs obtained in a plate after a 1:20 dilution in sterile saline solution. Each set of three values corresponds to replicates. Letters in superscript correspond to the respective control in each independent day $(n)$. Values between brackets were excluded from statistical analysis due to high deviating values or due to contamination; Table S6: Amino acid sequences of constructions. Genetic constructions were obtained by standard genetic engineering techniques using DNA sequences optimized for Escherichia coli codon usage. Genetic sequences coding for AMPs were cloned at the $\mathrm{N}$-terminus of A200 and SELP polymers and were chemically synthesized with flanking NdeI and KpnI restriction sites (A200-based constructions) or with flanking NdeI restriction sites (SELP-based constructions). The full amino acid sequences are presented below. The sequences coding for the AMPs are in red color and emphasized in bold.

Author Contributions: Conceptualization, A.M.P., M.C. and R.M.; methodology, A.M.P., D.G., A.d.C. and R.M.; software analysis, A.M.P. and R.M.; validation, A.M.P., D.G., A.d.C., M.C. and R.M.; formal analysis, A.M.P. and R.M.; investigation, A.M.P., D.G. and A.d.C.; resources, S.C.D., M.C. and R.M.; data curation, A.M.P. and D.G.; writing — original draft preparation, A.M.P.; writing—review and editing, D.G., A.d.C., S.C.D., M.C. and R.M.; supervision, M.C. and R.M.; funding acquisition, M.C. and R.M. All authors have read and agreed to the published version of the manuscript.

Funding: This work was supported by the "Contrato-Programa" UIDB/04050/2020, project FunBioPlas (ERA-IB-2-6/0004/2014) and project FUN2CYT (POCI-01-0145-FEDER-030568) funded by Portugal national funds through the Fundação para a Ciência e a Tecnologia (FCT I.P.). A.M.P. acknowledges the Doctoral Programme in Applied and Environmental Microbiology (DP_AEM) and FCT I.P. for the PD/BD/113811/2015 grant. R.M. acknowledges FCT I.P. for funding in the scope of the Scientific Employment Stimulus instrument (CEECIND/00526/2018).

Institutional Review Board Statement: Not applicable. 
Informed Consent Statement: Not applicable.

Data Availability Statement: Data is contained within the article or supplementary information.

Conflicts of Interest: The authors declare no conflict of interest.

\section{References}

1. Yang, Y.J.; Holmberg, A.L.; Olsen, B.D. Artificially engineered protein polymers. Annu. Rev. Chem. Biomol. Eng. 2017, 8, 549-575. [CrossRef]

2. Abascal, N.C.; Regan, L. The past, present and future of protein-based materials. R. Soc. Open Biol. 2018, 8, 180113. [CrossRef] [PubMed]

3. Qian, Z.-G.; Pan, F.; Xia, X.-X. Synthetic biology for protein-based materials. Curr. Opin. Biotechnol. 2020, 65, 197-204. [CrossRef]

4. Rabotyagova, O.S.; Cebe, P.; Kaplan, D.L. Protein-based block copolymers. Biomacromolecules 2011, 12, 269-289. [CrossRef]

5. Machado, R.; Da Costa, A.; Sencadas, V.; Pereira, A.M.; Collins, T.; Rodríguez-Cabello, J.C.; Lanceros-Méndez, S.; Casal, M. Exploring the properties of genetically engineered silk-elastin-like protein films. Macromol. Biosci. 2015, 15, 1698-1709. [CrossRef] [PubMed]

6. Machado, R.; Azevedo-Silva, J.; Correia, C.; Collins, T.; Arias, F.J.; Rodriguez-Cabello, J.C.; Casal, M. High level expression and facile purification of recombinant silk-elastin-like polymers in auto induction shake flask cultures. AMB Express $2013,3,11$. [CrossRef] [PubMed]

7. Acosta, S.; Ibañez-Fonseca, A.; Aparicio, C.; Rodríguez-Cabello, J.C. Antibiofilm coatings based on protein-engineered polymers and antimicrobial peptides for preventing implant-associated infections. Biomater. Sci. 2020, 8, 2866-2877. [CrossRef]

8. da Costa, A.; Pereira, A.M.; Sampaio, P.; Rodríguez-Cabello, J.C.; Gomes, A.C.; Casal, M.; Machado, R. Protein-Based Films Functionalized with a Truncated Antimicrobial Peptide Sequence Display Broad Antimicrobial Activity. ACS Biomater. Sci. Eng. 2021, 7, 451-461. [CrossRef] [PubMed]

9. Gomes, S.C.; Leonor, I.B.; Mano, J.F.; Reis, R.L.; Kaplan, D.L. Antimicrobial functionalized genetically engineered spider silk. Biomaterials 2011, 32, 4255-4266. [CrossRef]

10. Franco, A.R.; Fernandes, E.M.; Rodrigues, M.T.; Rodrigues, F.J.; Gomes, M.E.; Leonor, I.B.; Kaplan, D.L.; Reis, R.L. Antimicrobial coating of spider silk to prevent bacterial attachment on silk surgical sutures. Acta Biomater. 2019, 99, 236-246. [CrossRef]

11. Acosta, S.; Quintanilla, L.; Alonso, M.; Aparicio, C.; Rodríguez-Cabello, J.C. Recombinant AMP/Polypeptide Self-Assembled Monolayers with Synergistic Antimicrobial Properties for Bacterial Strains of Medical Relevance. ACS Biomater. Sci. Eng. 2019, 5 , 4708-4716. [CrossRef]

12. da Costa, A.; Machado, R.; Ribeiro, A.; Collins, T.; Thiagarajan, V.; Neves-Petersen, M.T.; Rodríguez-Cabello, J.C.; Gomes, A.C.; Casal, M. Development of elastin-like recombinamer films with antimicrobial activity. Biomacromolecules 2015, 16, 625-635. [CrossRef]

13. da Costa, A.; Pereira, A.M.; Gomes, A.C.; Rodríguez-Cabello, J.C.; Sencadas, V.; Casal, M.; Machado, R. Single step fabrication of antimicrobial fibre mats from a bioengineered protein-based polymer. Biomed. Mater. 2017, 12, 045011. [CrossRef]

14. Yigit, S.; Dinjaski, N.; Kaplan, D.L. Fibrous proteins: At the crossroads of genetic engineering and biotechnological applications. Biotechnol. Bioeng. 2016, 113, 913-929. [CrossRef]

15. Ibáñez-Fonseca, A.; Flora, T.; Acosta, S.; Rodríguez-Cabello, J.C. Trends in the design and use of elastin-like recombinamers as biomaterials. Matrix Biol. 2019, 84, 111-126. [CrossRef]

16. Girotti, A.; Fernández-Colino, A.; López, I.M.; Rodríguez-Cabello, J.C.; Arias, F.J. Elastin-like recombinamers: Biosynthetic strategies and biotechnological applications. Biotechnol. J. 2011, 6, 1174-1186. [CrossRef]

17. Urry, D.W.; Hayes, L.C.; Gowda, D.C.; Harris, C.M.; Harris, R.D. Reduction-driven polypeptide folding by the $\Delta$ Tt mechanism. Biochem. Biophys. Res. Commun. 1992, 188, 611-617. [CrossRef]

18. Rodriguez-Cabello, J.C. Smart elastin-like polymers. In Biomaterials. Advances in Experimental Medicine and Biology; Springer: Boston, MA, USA, 2004. [CrossRef]

19. Megeed, Z.; Cappello, J.; Ghandehari, H. Genetically engineered silk-elastinlike protein polymers for controlled drug delivery. Adv. Drug Deliv. Rev. 2002, 54, 1075-1091. [CrossRef]

20. Brogden, K.A. Antimicrobial peptides: Pore formers or metabolic inhibitors in bacteria? Nat. Rev. Genet. 2005, 3, 238-250. [CrossRef] [PubMed]

21. Mookherjee, N.; Anderson, M.A.; Haagsman, H.P.; Davidson, D.J. Antimicrobial host defence peptides: Functions and clinical potential. Nat. Rev. Drug Discov. 2020, 19, 311-332. [CrossRef]

22. Jenssen, H.; Hamill, P.; Hancock, R.E. Peptide antimicrobial agents. Clin. Microbiol. Rev. 2006, 19, 491-511. [CrossRef]

23. Matsuzaki, K. Control of cell selectivity of antimicrobial peptides. Biochim. Biophys. Acta (BBA) Biomembr. 2009, 1788, 1687-1692. [CrossRef]

24. Lai, Y.; Gallo, R.L. AMPed up immunity: How antimicrobial peptides have multiple roles in immune defense. Trends Immunol. 2009, 30, 131-141. [CrossRef] [PubMed]

25. Spohn, R.; Daruka, L.; Lázár, V.; Martins, A.; Vidovics, F.; Grézal, G.; Méhi, O.; Kintses, B.; Számel, M.; Jangir, P.K. Integrated evolutionary analysis reveals antimicrobial peptides with limited resistance. Nat. Commun. 2019, 10, 1-13. [CrossRef]

26. Takahashi, D.; Shukla, S.K.; Prakash, O.; Zhang, G. Structural determinants of host defense peptides for antimicrobial activity and target cell selectivity. Biochimie 2010, 92, 1236-1241. [CrossRef] [PubMed] 
27. Pfalzgraff, A.; Brandenburg, K.; Weindl, G. Antimicrobial peptides and their therapeutic potential for bacterial skin infections and wounds. Front. Pharmacol. 2018, 9, 281. [CrossRef]

28. Pasupuleti, M.; Schmidtchen, A.; Malmsten, M. Antimicrobial peptides: Key components of the innate immune system. Crit. Rev. Biotechnol. 2012, 32, 143-171. [CrossRef] [PubMed]

29. Li, J.; Koh, J.-J.; Liu, S.; Lakshminarayanan, R.; Verma, C.S.; Beuerman, R.W. Membrane active antimicrobial peptides: Translating mechanistic insights to design. Front. Neurosci. 2017, 11, 73. [CrossRef]

30. Moravej, H.; Moravej, Z.; Yazdanparast, M.; Heiat, M.; Mirhosseini, A.; Moosazadeh Moghaddam, M.; Mirnejad, R. Antimicrobial peptides: Features, action, and their resistance mechanisms in bacteria. Microb. Drug Resist. 2018, 24, 747-767. [CrossRef] [PubMed]

31. Wang, Y.; Zhang, J.; Gao, T.; Zhang, N.; He, J.; Wu, F. Covalent immobilization of DJK-5 peptide on porous titanium for enhanced antibacterial effects and restrained inflammatory osteoclastogenesis. Colloids Surf. B Biointerfaces 2021, 202, 111697. [CrossRef]

32. Song, D.W.; Kim, S.H.; Kim, H.H.; Lee, K.H.; Ki, C.S.; Park, Y.H. Multi-biofunction of antimicrobial peptide-immobilized silk fibroin nanofiber membrane: Implications for wound healing. Acta Biomater. 2016, 39, 146-155. [CrossRef]

33. Boix-Lemonche, G.; Guillem-Marti, J.; Lekka, M.; D’Este, F.; Guida, F.; Manero, J.M.; Skerlavaj, B. Membrane perturbation, altered morphology and killing of Staphylococcus epidermidis upon contact with a cytocompatible peptide-based antibacterial surface. Colloids Surf. B Biointerfaces 2021, 203, 111745. [CrossRef] [PubMed]

34. Fischer, N.G.; Chen, X.; Astleford-Hopper, K.; He, J.; Mullikin, A.F.; Mansky, K.C.; Aparicio, C. Antimicrobial and enzymeresponsive multi-peptide surfaces for bone-anchored devices. Mater. Sci. Eng. C Mater. Biol. Appl. 2021, 125, 112108. [CrossRef]

35. Onaizi, S.A.; Leong, S.S. Tethering antimicrobial peptides: Current status and potential challenges. Biotechnol. Adv. 2011, 29, 67-74. [CrossRef]

36. Bagheri, M.; Beyermann, M.; Dathe, M. Immobilization Reduces the Activity of Surface-Bound Cationic Antimicrobial Peptides with No Influence upon the Activity Spectrum. Antimicrob. Agents Chemother. 2009, 53, 1132. [CrossRef]

37. Hasan, J.; Crawford, R.J.; Ivanova, E.P. Antibacterial surfaces: The quest for a new generation of biomaterials. Trends Biotechnol. 2013, 31, 295-304. [CrossRef]

38. Alves, D.; Olívia Pereira, M. Mini-review: Antimicrobial peptides and enzymes as promising candidates to functionalize biomaterial surfaces. Biofouling 2014, 30, 483-499. [CrossRef]

39. Kazemzadeh-Narbat, M.; Cheng, H.; Chabok, R.; Alvarez, M.M.; de la Fuente-Nunez, C.; Phillips, K.S.; Khademhosseini, A. Strategies for antimicrobial peptide coatings on medical devices: A review and regulatory science perspective. Crit. Rev. Biotechnol. 2021, 41, 94-120. [CrossRef] [PubMed]

40. Chouirfa, H.; Bouloussa, H.; Migonney, V.; Falentin-Daudre, C. Review of titanium surface modification techniques and coatings for antibacterial applications. Acta Biomater. 2019, 83, 37-54. [CrossRef] [PubMed]

41. Ahmadabadi, H.Y.; Yu, K.; Kizhakkedathu, J.N. Surface modification approaches for prevention of implant associated infections. Colloids Surf. B Biointerfaces 2020, 193, 111116. [CrossRef]

42. Atefyekta, S.; Pihl, M.; Lindsay, C.; Heilshorn, S.C.; Andersson, M. Antibiofilm elastin-like polypeptide coatings: Functionality, stability, and selectivity. Acta Biomater. 2019, 83, 245-256. [CrossRef]

43. Tiller, J.C.; Liao, C.-J.; Lewis, K.; Klibanov, A.M. Designing surfaces that kill bacteria on contact. Proc. Natl. Acad. Sci. USA 2001, 98, 5981-5985. [CrossRef]

44. Lewis, K.; Klibanov, A.M. Surpassing nature: Rational design of sterile-surface materials. Trends Biotechnol. 2005, 23, 343-348. [CrossRef]

45. da Costa, A.; Pereira, A.M.; Gomes, A.C.; Rodriguez-Cabello, J.C.; Casal, M.; Machado, R. Production of bioactive hepcidin by recombinant DNA tagging with an elastin-like recombinamer. New Biotechnol. 2018, 46, 45-53. [CrossRef]

46. Machado, R.; Ribeiro, A.J.; Padrão, J.; Silva, D.; Nobre, A.; Teixeira, J.; Arias, F.; Cunha, A.M.; Rodríguez-Cabello, J.C.; Casal, M. Exploiting the sequence of naturally occurring elastin: Construction, production and characterization of a recombinant thermoplastic protein-based polymer. J. Nano Res. 2009, 6, 133-145. [CrossRef]

47. Machado, R.; Bessa, P.C.; Reis, R.L.; Rodriguez-Cabello, J.C.; Casal, M. Elastin-based nanoparticles for delivery of bone morphogenetic proteins. In Nanoparticles in Biology and Medicine. Methods in Molecular Biology (Methods and Protocols); Humana Press: Totowa, NJ, USA, 2012. [CrossRef]

48. Freire, D.O.; da Cunha, N.B.; Leite, M.L.; Kostopoulos, A.G.; da Silva, S.N.; de Souza, A.C.; Nolasco, D.O.; Franco, O.L.; Mortari, M.R.; Dias, S.C. Wasp venom peptide, synoeca-MP, from Synoeca surinama shows antimicrobial activity against human and animal pathogenic microorganisms. Pept. Sci. 2019, 112, e24141. [CrossRef]

49. Park, C.H.; Valore, E.V.; Waring, A.J.; Ganz, T. Hepcidin, a urinary antimicrobial peptide synthesized in the liver. J. Biol. Chem. 2001, 276, 7806-7810. [CrossRef]

50. Krause, A.; Neitz, S.; Mägert, H.-J.; Schulz, A.; Forssmann, W.-G.; Schulz-Knappe, P.; Adermann, K. LEAP-1, a novel highly disulfide-bonded human peptide, exhibits antimicrobial activity. FEBS Lett. 2000, 480, 147-150. [CrossRef]

51. Chen, Y.Q.; Min, C.; Sang, M.; Han, Y.Y.; Ma, X.; Xue, X.Q.; Zhang, S.Q. A cationic amphiphilic peptide ABP-CM4 exhibits selective cytotoxicity against leukemia cells. Peptides 2010, 31, 1504-1510. [CrossRef]

52. Li, B.-C.; Zhang, S.-Q.; Dan, W.-B.; Chen, Y.-Q.; Cao, P. Expression in Escherichia coli and purification of bioactive antibacterial peptide ABP-CM4 from the Chinese silk worm, Bombyx mori. Biotechnol. Lett. 2007, 29, 1031-1036. [CrossRef] 
53. Mardirossian, M.; Pompilio, A.; Crocetta, V.; De Nicola, S.; Guida, F.; Degasperi, M.; Gennaro, R.; Di Bonaventura, G.; Scocchi, $\mathrm{M}$. In vitro and in vivo evaluation of BMAP-derived peptides for the treatment of cystic fibrosis-related pulmonary infections. Amino Acids 2016, 48, 2253-2260. [CrossRef]

54. Lee, E.K.; Kim, Y.-C.; Nan, Y.H.; Shin, S.Y. Cell selectivity, mechanism of action and LPS-neutralizing activity of bovine myeloid antimicrobial peptide-18 (BMAP-18) and its analogs. Peptides 2011, 32, 1123-1130. [CrossRef]

55. Lombardi, L.; Maisetta, G.; Batoni, G.; Tavanti, A. Insights into the antimicrobial properties of hepcidins: Advantages and drawbacks as potential therapeutic agents. Molecules 2015, 20, 6319-6341. [CrossRef]

56. Machado, R.; Da Costa, A.; Sencadas, V.; Garcia-Arévalo, C.; Costa, C.M.; Padrao, J.; Gomes, A.; Lanceros-Méndez, S.; RodríguezCabello, J.C.; Casal, M. Electrospun silk-elastin-like fibre mats for tissue engineering applications. Biomed. Mater. 2013, 8, 065009. [CrossRef] [PubMed]

57. Franco, A.R.; Palma Kimmerling, E.; Silva, C.; Rodrigues, F.J.; Leonor, I.B.; Reis, R.L.; Kaplan, D.L. Silk-based antimicrobial polymers as a new platform to design drug-free materials to impede microbial infections. Macromol. Biosci. 2018, 18, 1800262. [CrossRef] [PubMed]

58. Pereira, A.M.; Machado, R.; da Costa, A.; Ribeiro, A.; Collins, T.; Gomes, A.C.; Leonor, I.B.; Kaplan, D.L.; Reis, R.L.; Casal, M. Silk-based biomaterials functionalized with fibronectin type II promotes cell adhesion. Acta Biomater. 2017, 47, 50-59. [CrossRef] [PubMed]

59. Teng, W.; Cappello, J.; Wu, X. Recombinant silk-elastinlike protein polymer displays elasticity comparable to elastin. Biomacromolecules 2009, 10, 3028-3036. [CrossRef]

60. Lyons, R.E.; Lesieur, E.; Kim, M.; Wong, D.C.; Huson, M.G.; Nairn, K.M.; Brownlee, A.G.; Pearson, R.D.; Elvin, C.M. Design and facile production of recombinant resilin-like polypeptides: Gene construction and a rapid protein purification method. Protein Eng. Des. Sel. 2007, 20, 25-32. [CrossRef] [PubMed]

61. Bandekar, J. Amide modes and protein conformation. Biochim. Biophys. Acta (BBA) Protein Struct. Mol. Enzymol. 1992, 1120, 123-143. [CrossRef]

62. Surewicz, W.K.; Mantsch, H.H.; Chapman, D. Determination of protein secondary structure by Fourier transform infrared spectroscopy: A critical assessment. Biochemistry 1993, 32, 389-394. [CrossRef]

63. Hu, X.; Kaplan, D.; Cebe, P. Determining Beta-Sheet Crystallinity in Fibrous Proteins by Thermal Analysis and Infrared Spectroscopy. Macromolecules 2006, 39, 6161-6170. [CrossRef]

64. Arrondo, J.L.R.; Goñi, F.M. Structure and dynamics of membrane proteins as studied by infrared spectroscopy. Prog. Biophys. Mol. Biol. 1999, 72, 367-405. [CrossRef]

65. Susi, H.; Michael Byler, D. Protein structure by Fourier transform infrared spectroscopy: Second derivative spectra. Biochem. Biophys. Res. Commun. 1983, 115, 391-397. [CrossRef]

66. Kong, J.; Yu, S. Fourier transform infrared spectroscopic analysis of protein secondary structures. Acta Biochim. Biophys. Sin. 2007, 39, 549-559. [CrossRef]

67. Yang, H.; Yang, S.; Kong, J.; Dong, A.; Yu, S. Obtaining information about protein secondary structures in aqueous solution using Fourier transform IR spectroscopy. Nat. Protoc. 2015, 10, 382-396. [CrossRef]

68. Rauscher, S.; Pomès, R. The liquid structure of elastin. Elife 2017, 6, e26526. [CrossRef]

69. Quintanilla-Sierra, L.; García-Arévalo, C.; Rodriguez-Cabello, J. Self-assembly in elastin-like recombinamers: A mechanism to mimic natural complexity. Mater. Today Bio 2019, 2, 100007. [CrossRef]

70. Wilson, D.; Valluzzi, R.; Kaplan, D. Conformational transitions in model silk peptides. Biophys. J. 2000, 78, 2690-2701. [CrossRef]

71. Rabotyagova, O.S.; Cebe, P.; Kaplan, D.L. Role of polyalanine domains in $\beta$-sheet formation in spider silk block copolymers. Macromol. Biosci. 2009, 10, 49-59. [CrossRef]

72. Haaber, J.; Cohn, M.T.; Frees, D.; Andersen, T.J.; Ingmer, H. Planktonic aggregates of Staphylococcus aureus protect against common antibiotics. PLoS ONE 2012, 7, e41075. [CrossRef]

73. Skerlavaj, B.; Gennaro, R.; Bagella, L.; Merluzzi, L.; Risso, A.; Zanetti, M. Biological characterization of two novel cathelicidinderived peptides and identification of structural requirements for their antimicrobial and cell lytic activities. J. Biol. Chem. 1996, 271, 28375-28381. [CrossRef] [PubMed]

74. Li, J.F.; Zhang, J.; Xu, X.Z.; Han, Y.Y.; Cui, X.W.; Chen, Y.Q.; Zhang, S.Q. The antibacterial peptide ABP-CM4: The current state of its production and applications. Amino Acids 2012, 42, 2393-2402. [CrossRef]

75. Jordan, J.B.; Poppe, L.; Haniu, M.; Arvedson, T.; Syed, R.; Li, V.; Kohno, H.; Kim, H.; Schnier, P.D.; Harvey, T.S.; et al. Hepcidin revisited, disulfide connectivity, dynamics, and structure. J. Biol. Chem. 2009, 284, 24155-24167. [CrossRef]

76. Taraballi, F.; Natalello, A.; Campione, M.; Villa, O.; Doglia, S.M.; Paleari, A.; Gelain, F. Glycine-spacers influence functional motifs exposure and self-assembling propensity of functionalized substrates tailored for neural stem cell cultures. Front. Neuroeng. 2010, 3, 1. [CrossRef] [PubMed]

77. van Rosmalen, M.; Krom, M.; Merkx, M. Tuning the flexibility of glycine-serine linkers to allow rational design of multidomain proteins. Biochemistry 2017, 56, 6565-6574. [CrossRef]

78. Gabriel, M.; Nazmi, K.; Veerman, E.C.; Nieuw Amerongen, A.V.; Zentner, A. Preparation of LL-37-grafted titanium surfaces with bactericidal activity. Bioconjugate Chem. 2006, 17, 548-550. [CrossRef] [PubMed]

79. Hu, X.; Kaplan, D.L. 2.212-Silk Biomaterials. In Comprehensive Biomaterials; Ducheyne, P., Ed.; Elsevier: Oxford, UK, 2011. 